\title{
PENYELESAIAN PERSELISIHAN HUBUNGAN INDUSTRIAL MELALUI LEMBAGA ARBITRASE HUBUNGAN INDUSTRIAL
}

\author{
Bambang Yunarko \\ Fakultas Hukum Universitas Wijaya Kusuma Surabaya \\ e-mail:@yahoo.com
}

\begin{abstract}
ABSTRAK
Penyelesaian sengketa tidak diselesaikan di pengadilan, tetapi juga dapat diselesaikan melalui pengadilan umum dikenal sebagai penyelesaian sengketa alternatif, salah satunya adalah arbitrase. Hubungan industrial arbitrase untuk menyelesaikan perselisihan kepentingan dan hanya perselisihan antar serikat pekerja atau buruh di satu perusahaan. Undang-Undang Nomor 2 Tahun 2004 tentang Hubungan Industrial, khususnya arbitrase hubungan industrial Indonesia sesuai dengan prinsip lex specialis derogat lex generali.
\end{abstract}

Kata Kunci: Penyelesaian, Hubungan Industrial, Arbitrase Hubungan Industrial

\section{ABSTRACT}

The solution of dispute of shouldn't be resolved in the court, in the court, but also can be resolved through but also can be resolved through the courts of commonly be known as alternative dispute solution, one of which is arbitration. Industrial relations arbitration to resolve disputes only the interest and disputes between union/union workers at one company. Act No. 2 of 2004 about industrial relations, specifically arrange the particulars of arbitration of industrial relations in Indonesia accord with principle lex specialis derogat lex generali.

Keywords: Disputes, Industrial relations, Industrial relations arbitration.

\section{PENDAHULUAN}

Dengan berlakunya Undang-Undang Nomor 2 Tahun 2004 tentang Penyelesaian Perselisihan Hubungan Internasional dihubungkan dengan Peraturan Pelaksanaan Tentang Penyelesaian Perselisihan Hubungan Industrial diperoleh suatu gambaran bahwa proses penyelesaian hubungan industri itu telah mengalami perkembangan yang cukup kompleks. Disebut sifat kompleks karena penanganan perselisihan itu saat dapat ditempuh dalam (2) dua jalur, yaitu: Pertama, Jalur Peradilan: Penyelesaian perselisihan melalui jalur peradilan telah diatur dalam sisitim peradilan bahwa tenaga Hakim sudah ditambah dengan Hakim Ad-Hoc, yang proses litigasinya berjalan diperadilan umum. Sistim peradilan di peradilan umum hanya terdiri dari 2 (dua) tingkat yakni, penyelesaian perselisihan hubungan industrial di tingkat pertama dan tingkat kasasi, perubahan ini secara nyata adalah mengganti sistim peradilan semu yang semula perselisihan perburuhan ditangani P4D atau P4P. Sistim ini diharapkan akan lebih efektif agar dengan cara itu Hakim dalam peradilan hubungan industrial sudah menerapkan aspek keadilan hukum terhadap kaum buruh maupun pengusaha. Kedua, Penanganan Perselisihan di Luar Pengadilan, yaitu: (a) konsiliasi; (b) arbitrase; (c) mediasi
Tujuan kedua sistem penyelesaian perselisihan hubungan industrial itu adalah, untuk: (a) Menciptakan ketenangan atau ketentraman dalam kerja serta ketenangan usaha; (b) Meningkatkan produksi; (c) Meningkatkan kesejahteraan pekerja serta derajatnya sesuai dengan martabat manusia, oleh karena itu hubungan industrial Pancasila harus dilaksanakan sesuai dengan asas tri kemitraan (three partnership) yaitu partnership in responsibility, partnership inproduction, dan partnership in profit.

Penyelesaian perselisihan perburuhan dahulu dilandaskan pada Undang-Undang Nomor 22 Tahun 1957 tentang Penyelesaian Perselisihan Perburuhan, yang selanjutnya disebut Undang-Undang Nomor 22 Tahun 1957. Namun seiring dengan perkembangan jaman, maka Undang-Undang Nomor 22 Tahun 1957 tidak sesuai lagi dengan perkembangan keadaan dan kebutuhan di atas, hal ini disebabkan oleh beberapa hal, pertama, Putusan Panitia Penyelesaian Perselisihan Perburuhan yang selanjutnya disingkat dengan P4-Pusat yang semula final, pihak yang tidak menerima putusan tersebut dapat mengajukan gugatan pada pengadilan tingkat tinggi tata usaha negara, selanjutnya dapat dimohonkan kasasi pada Mahkamah Agung.

Proses ini membutuhkan waktu yang relatif lama serta sangat tidak sesuai jika diterapkan 
dalam kasus ketenagakerjaan (hubungan industrial) yang memerlukan penyelesaian perkara secara cepat, karena berkaitan dengan proses produksi dan hubungan kerja. Kedua, adanya kewenangan Menteri untuk menunda atau membatalkan putusan P4-Pusat atau yang biasa disebut hak veto. Hak veto dianggap merupakan campur tangan Pemerintah dan tidak sesuai dengan Paradigma yang berkembang di masyarakat, dimana peranan Pemerintah seharusnya harus dikurangi. Ketiga, dalam Undang-Undang Nomor 22 Tahun 1957 yang dapat menjadi pihak dalam penyelesaian hubungan industrial hanyalah serikat pekerja atau serikat buruh. (Adrian Sutedi, 2009: 104).

Penyelesaian perselisihan yang terbaik adalah penyelesaian oleh para pihak yang berselisih, sehingga dapat diperoleh hasil yang menguntungkan bagi kedua belah pihak. (Abdussalam, 2008: 155). Namun demikian, pemerintah dalam upayanya untuk memberikan pelayanan masyarakat khususnya kepada masyarakat pekerja atau buruh dan pengusaha, berkewajiban memfasilitasi penyelesaian perselisihan hubungan industrial tersebut.

Upaya fasilitasi dilakukan dengan menyediakan tenaga mediator yang bertugas untuk mempertemukan kepentingan kedua belah pihak yang berselisih. Dengan adanya era demokrasi di segala bidang, maka perlu diakomodasi ketertiban masyarakat dalam menyelesaikan perselisihan hubungan industrial melalui negoisasi, konsiliasi, atau arbitrase.

Penyelesaian perselisihan melalui arbitrase pada umumnya, telah diatur di dalam Undang-Undang Nomor 30 Tahun 1999 tentang Arbitrase dan Alternatif Penyelesaian Sengketa, yang selanjutnya disebut Undang-Undang Nomor 30 Tahun 1999. Notabene pembentukan Undang-Undang Nomor 30 Tahun 1999 ini merupakan suatu upaya untuk menjawab tuntutan akselerasi dan dinamika masyarakat dalam memanajemen konflik komersial yang volume dan dentitasnya semakin kompleks. Namun demikian, meskipun arbitrase telah diatur dalam sebuah Undang-Undang tersendiri, tetapi di dalam Undang-Undang Nomor 30 Tahun 1999 tersebut sama sekali tidak menetapkan lembaga arbitrase sebagai peradilan Negara. Arbitrase hanyalah menjadi sebuah cara yang dipilih oleh pihak yang bersengketa untuk memberikan putusan mengenai sengketa tertentu.
Bahkan sengketa yang dapat diselesaikan melalui arbitrase itupun secara limitative disebutkan yaitu hanya sengketa perdata secara sempit dan sengketa dalam bidangperdagangan.

Arbitrase yang terdapat dalam Undang-Undang Nomor 30 Tahun 1999 merupakan bentuk pengaturan khusus, sedangkan arbitrase untuk penyelesaian perselisihan hubungan industrial belum ditetapkan dan dibentuk secara khusus. Dengan adanya kebutuhan akan suatu pengaturan khusus mengenai penyelesaian perselisihan hubungan industrial yang sesuai dengan keadaan jaman sekarang, maka pemerintah Republik Indonesia mensahkan dan memberlakukan Undang-Undang Nomor 2 Tahun 2004 tentang Penyelesaian Perselisihan Hubungan Industrial yang kemudian disebut Undang-Undang Nomor 2 Tahun 2004. Undang-Undang Nomor 2 Tahun 2004 ini diakui sebagai pengaturan khusus bagi penyelesaian perselisihan hubungan industrial, sesuai dengan asas hukum lex specialis derogad lex generali.

Ketentuan peralihan yang terdapat dalam Pasal 125 menyebutkan bahwa dengan berlakunya Undang-Undang ini (Undang-Undang Nomor 2 Tahun 2004), maka Undang-Undang Nomor 22 Tahun 1957 tentang Penyelesaian Perselisihan Perburuhan dinyatakan tidak berlaku lagi.

Di dalam Undang-Undang Nomor 2 Tahun 2004 ini diatur mengenai bentuk penyelesaian perselisihan hubungan industrial, di antaranya dapat melalui jalur litigasi yaitu pada pengadilan hubungan industrial, kemudian dapat pula melalui jalur non litigasi yaitu meliputi penyelesaian perselisihan hubungan industrial dengan cara bipartite, mediasi, konsiliasi dan arbitrase.

Perumusan mengenai Perselisihan hubungan industrial di dalam Undang-Undang Nomor 13 Tahun 2003 tentang Ketenagakerjaan, yang selanjutnya disebut Undang-Undang Nomor 13 Tahun 2003, bahkan memperluas lingkup perselisihan perburuhan yang tidak sematamata antara pekerja atau buruh dengan majikan dalam posisi yang bersebrangan akan tetapi juga perselisihan antar sesama pekerja atau buruh dalam satu perusahaan. Berikut adalah definisi perselisihan hubungan industrial menurut ketentuan Pasal 1 angka 22 Undang-Undang Nomor 13 Tahun 2003 disebutkan bahwa Perselisihan hubungan industrial adalah perbedaan pendapat yang mengakibatkan pertentangan antara pengusaha atau gabungan pengusaha dengan pekerja atau buruh dan/atau 
serikat pekerja atau serikat buruh.

Adanya perselisihan mengenai hak, perselisihan kepentingan, perselisihan permulaan hubungan kerja serta perselisihan antar serikat pekerja/ serikat buruh hanya dalam suatu perusahaan. Pemberlakuan Undang-Undang Nomor 2 Tahun 2004 sebagai peraturan khusus yang mengatur mengenai penyelesaian perselisihan hubungan industrial membuat penulis tertarik untuk melakukan penulisan mengenai suatu bentuk dan pelaksanaan penyelesaian perselisihan hubungan industrial. Namun pada kesempatan ini penulis sangat tertarik memfokuskan pada penyelesaian perselisihan hubungan industrial melalui arbitrase. Adapun alasan penulis tertarik pada pokok penulisan arbitrase hubungan industrial karena masih banyak masyarakat luas yang kurang tahu tentang arbitrase sebagai alternatif penyelesaian perselisihan hubungan industrial dan sebenarnya selain melalui pengadilan hubungan industrial, sesungguhnya penyelesaian perselisihan hubungan industrial dapat diselesaikan melalui jalur diluar pengadilan yaitu salah satunya melalui arbitrae hubungan industrial.

\section{JENIS PERSELESAIAN HUBUNGAN INDUSTRIAL}

Sesuai dengan tata hukum di Indonesia Pasal 1 angka I Nomor 2 Tahun 2004 memberikan pengertian tentang perselisihan hubungan industrial. Perselisihan Hubungan Industrial adalah perbedaan pendapat yang mengakibatkan pertentangan antara pengusaha atau gabungan pengusaha dengan pekerja/buruh atau serikat pekerja/serikat buruh karena adanya perselisihan mengenai hak, perselisihan kepentingan, perselisihan pemutusan hubungan kerja dan perselisihan antar serikat pekerja/serikat buruh dalam satu perusahaan. Dari pengertian di atas maka semakin jelas bahwa perselisihan hubungan industrial meliputi perselisihan hak, perselisihan antar serikat pekerja dalam satu perusahaan.

Berikut ini adalah beberapa pengertian perselisihan di atas: Pertama, Perselisihan Hak. Perselisihan hak merupakan perselisihan hukum karena perselisihan ini terjadi akibat pelanggaran kesepakatan yang telah dibuat oleh para pihak. Pelanggaran tersebut termasuk didalamnya hal-hal yang sudah ditentukan dalam peraturan perusahaan serta peraturan perundang-undangan yang berlaku. (Lalu Husni, 2007: 45). Karena itu, menurut Imam Soepomo, perselisihan hak terjadi karena tidak adanya persesuaian paham mengenai pelaksanaan hubungan kerja; Kedua, Perselisihan Kepentingan. Perselisihan kepentingan disebut juga belangen geschil, menurut Imam Soepomo terjadi karena ketidak sesuaian paham dalam perubahan syarat-syarat kerja atau keadaan perburuhan. Dari pengertian di atas jelaslah perbedaan antara kedua jenis perselisihan tersebut, yakni perselisihan hak objek sengketanya adalah tidak dipenuhinya hak yang telah ditetapkan karena adanya perbedaan dalam implementasi atau penafsiran ketentuan peraturan perundang-undangan, perjanjian kerja, peraturan perusahaan, atau perjanjian kerja bersama yang melandasi hak yang disengketakan. Sedangkan dalam perselisihan kepentingan, objek sengketanya karena tidak adanya kesesuaian paham/pendapat mengenai pembuatan, dan/atau perubahan syaratsyarat kerja yang ditetapkan dalam perjanjian kerja, atau peraturan perselisihan, atau perjanjian kerja bersama. (i) Perselisihan Pemutusan Hubungan Kerja; Perselisihan Pemutusan Hubungan Kerja (PHK) adalah perselisihan yang timbul adanya kesesuaian pendapat mengenai pengakhiran hubungan kerja yang dilakukan oleh salah satu pihak (Pasal 1 angka 4 Undang-Undang Nomor 2 Tahun 2004). Perselisihan mengenai PHK selama ini paling banyak terjadi karena tindakan PHK yang dilakukan oleh satu pihak dan pihak lain tidak dapat menerimanya. (ii) Perselisihan antar Serikat Pekerja/Serikat Buruh dalam Satu Perusahaan Perselisihan antar serikat pekerja/serikat buruh adalah perselisihan antara serikat pekerja/serikat buruh dengan serikat pekerja/serikat buruh lain hanya dalam satu perusahaan. Perselisihan tersebut terjadi karena tidak adanya persesuaian paham mengenai keanggotaan pelaksanaan hak, dan kewajiban keserikat pekerjaan (Pasal 1 angka 5 Undang-Undang Nomor 2 Tahun 2004). Sejalan dengan era keterbukaan dan demokratisasi dalam dunia industri yang diwujudkan dengan kebebasan untuk berserikat bagi pekerja/buruh sehingga jumlah serikat pekerja/buruh disuatu perusahaan tidak dapat dibatasi. Kebebasan berserikat bagi pekerja/buruh merupakan hak dasar yang dilindungi dan dijamin secara konstitusional. (Bohder Johan Nasution, 2004: 1)

Untuk mewujudkan hak tersebut, pekerja/buruh harus diberi kesempatan yang seluas-luasnya untuk mendirikan dan menjadi anggota serikat pekerja/ buruh. Pendirian serikat pekerja/buruh berfungsi 
sebagai sarana untuk memperjuangkan, melindungi, dan membela kepentingan dan meningkatkan kesejahteraan pekerja dan keluarganya. Pembentukan organisasi serikat pekerja harus dilakukan secara demokratis, bebas, mandiri dan bertanggung jawab tanpa campur tangan atau pengaruh pihak manapun.

\section{PERSELISIHAN YANG DAPAT DISELESAI- KAN MELALUI ARBITRASE HUBUNGAN INDUSTRIAL}

Wilayah kerja arbitrase hubungan industrial dalam hal penyelesaian perselisihan hubungan industrial meliputi semua wilayah di negara Indonesia. Arbitrase juga mempunyai batasbatas kewenangan mengenai pekerja yang dapat diselesaikan melalui arbitrase hubungan industrial. Batasan tentang arbiter dan arbitrase hubungan industrial dalam Undang-Undang Nomor 2 Tahun 2004 tidak sama dengan Undang-Undang Nomor 30 Tahun 1999. Undang-Undang Nomor 2 Tahun 2004 secara spesifik merinci kompetensi arbitrase hubungan industrial yang hanya berwenang menyelesaikan perselisihan hubungan industrial untuk dua jenis perselisihan yaitu: Pertama, Perselisihan Kepentingan, yang didalam UndangUndang Nomor 2 Tahun 2004 didefinisikan sebagai perselisihan yang timbul dalam hubungan kerja karena tidak adanya kesesuaian pendapat mengenai pembuatan, dan/atau perubahan syarat-syarat kerja yang ditetapkan dalam perjanjian kerja bersama; Kedua, Perselisihan Antar Serikat Pekerja/Serikat Buruh, yang di dalam Undang-Undang Nomor 2 Tahun 2004 didefinisikan sebagai perselisihan antar serikat pekerja/serikat buruh dengan serikat pekerja/ serikat buruh lain hanya dalam satu perusahaan, karena tidak adanya kesesuaian paham mengenai keanggotaan, pelaksanaan hak, dan kewajiban keserikat pekerjaan.

\section{PENYELESAIAN PERSELISIHAN HUBU- NGAN INDUSTRI MELALUI ARBITRASE HUBUNGAN INDUSTRIAL}

Penyelesaian perselisihan hubungan industrial melalui arbitrase hubungan industrial yang dilakukan oleh arbiter harus diawali dengan upaya mendamaikan kedua belah pihak yang berselisih. Apabila perdamaian tersebut tercapai maka arbiter atau majelis arbiter wajib membuat akta perdamaian yang ditandatangani oleh para pihak yang berselisih dan arbiter. Akta perdamaian sebagaimana dimaksud di atas didaftarkan di pengadilan hubungan industrial pada pengadilan negeri di wilayah arbiter mengadakan perdamaian (Pasal 44 ayat 3 UndangUndang Nomor 2 Tahun 2004). Pendaftaran akta perdamaian dilakukan sebagai berikut: Pertama, Akta perdamaian yang telah didaftar diberikan akta bukti pendaftaran dan merupakan bagian yang tidak terpisahkan dari akta perdamaian; Kedua, Apabila akta perdamaian tidak dilaksanakan oleh salah satu pihak, maka pihak yang dirugikan dapat mengajukan permohonan eksekusi kepada pengadilan hubungan industrial pada pengadilan negeri di wilayah akta perdamaian didaftar untuk mendapat penetapan eksekusi; Ketiga, Dalam hal permohonan eksekusi berdomisili di luar wilayah hukum pengadilan hubungan industrial pada pengadilan negeri tempat pendaftaran akta perdamaian, maka pemohon eksekusi dapat mengajukan permohonan eksekusi kepada pengadilan hubungan industrial di wilayah domosili pemohon eksekusi untuk diteruskan ke pengadilan hubungan industrial pada pengadilan negeri yang berkompeten melaksanakan eksekusi. (Pasal 44 ayat 4 Undang-Undang Nomor 2 Tahun 2004).

Penyelesaian perselisihan hubungan industrial harus dilakukan melalui kesepakatan tertulis dari para pihak yang berselisih untuk menyerahkan penyelesaian perselisihannya serta putusannya agar mengikat para pihak dan bersifat final.

Undang-Undang Nomor 2 Tahun 2004 Pasal 32 ayat (3) mensyaratkan bahwa penyelesaian perselisihan melalui arbitrase dilakukan atas dasar kesepakatan para pihak yang berselisih dan dinyatakan secara tertulis dalam surat perjanjian arbitrase. Surat perjanjian arbitrase sekurangkurangnya memuat: Pertama, Nama lengkap dan alamat atau tempat kedudukan para pihak yang berselisih; Kedua, Pokok persoalan yang menjadi perselisihan dan yang diserahkan kepada arbitrase untuk diselesaikan dan diambil keputusan; Ketiga, Jumlah arbiter yang disepakati; Keempat, Pernyataan para pihak yang berselisih untuk tunduk dan menjalankan putusan arbitrase; dan Kelima, Tempat, tanggal pembuatan surat perjanjian, tanda tangan para pihak yang berselisih.

Jika para pihak sudah menandatangani surat perjanjian arbitrase, mereka berhak memilih arbiter dari daftar arbiter yang ditetapkan oleh Menteri tenaga kerja. Apabila arbiter telah tandatangan surat perjanjian, yang bersangkutan tidak dapat menarik diri kecuali atas persetujuan para pihak (Pasal 35 
ayat 1 Undang-Undang Nomor 2 Tahun 2004).

Perjanjian penunjukan arbiter sekurangkurangnya memuat: Pertama, Nama lengkap dan alamat atau tempat kedudukan para pihak yang berselisih dan arbiter; Kedua, Pokok-pokok yang menjadi persoalan yang menjadi perselisihan dan yang diserahkan kepada arbiter untuk diselesaikan dan diambil keputusan; Ketiga, Biaya arbitrase dan honorium arbiter; Keempat, Pernyataan para pihak yang berselisih untuk tunduk dan menjalankan keputusan arbitrase; Kelima, Tempat, tanggal pembuatan surat perjanjian, dan tandatangan para pihak yang berselisih dan arbiter; Keenam, Pernyataan arbiter atau para arbiter untuk tidak melampaui kewenangannya dalam penyelesaian perkara yang ditandatanganinya; dan Tidak mempunyai hubungan keluarga sedarah atau semenda sampai dengan derajat kedua dengan salah satu pihak yang berselisih.

Perjanjian penunjukan arbiter di atas sekurangkurangnya dibuat rangkap 3 (tiga). Setelah dibuat rangkap 3 selanjutnya masing-masing pihak dan arbiter mendapatkan 1 (satu), yang mem-punyai kekuatan hokum sama. Dalam hal arbitrase dilakukan oleh beberapa arbiter, maka asli dari perjanjian tersebut diberikan kepada ketua majelis arbiter. Dalam hal arbiter telahn menerima penunjukan dan menandatangani surat perjanjian tersebut, maka pihak yang bersangkutan tidak dapat menarik diri, kecuali atas persetujuan para pihak. Arbiter yang akan menarik diri harus mengajukan permohonan secara tertulis kepada para pihak.

Penyelesaian perselisihan hubungan industrial melalui arbitrase harus sudah diselesaikan dalam jangka 30 hari kerja sejak penandatanganan surat penunjukan arbiter. Perpanjangan waktu penyelesaian perselisihan hanya dapat dilakukan satu kali, yaitu sebanyak 14 hari kerja, itupun harus dengan persetujuan para pihak.

Selanjutnya perselisihan hubungan industrial yang sedang atau telah diselesaikan melalui arbitrase tidak dapat dilakukan ke pengadilan hubungan industrial (Pasal 53 Undang-Undang Nomor 2 Tahun 2004). Dalam proses persidangan, pertama kali yang harus dilakukan seorang arbiter adalah harus berusaha mendamaikan para pihak, sehingga perselisihan dapat terselesaikan secara kekeluargaan.

Apabila terjadi penyelesaian damai, maka arbiter akan membantu para pihak untuk membuat perjanjian bersama dan mendaftarkannya di pengadilan perselisihan hubungan industrial untuk mendapatkan bukti akta perdamaian. Namun apabila tidak terjadi penyelesaian secara damai dan kekeluargaan, arbiter akan mengeluarkan putusan yang bersifat final, yang harus diikuti oleh para pihak yang berselisih. Atas putusan arbiter tidak dapat diajukan gugatan ke pengadilan, karena putusan tersebut telah mempunyai kekuatan hukum yang mengikat para pihak, dan merupakan putusan akhir yang berkekuatan tetap.

Putusan arbitrase didaftarkan di pengadilan hubungan industrial yang berada di pengadilan, negeri yang di wilayah arbiter yang menetapkan ke-putusan. Apabila ada pihak yang tidak bersedia melaksanakan isi putusan arbitrase, pihak yang merasakan dirugikan dapat mengajukan permohonan fiat eksekusi di pengadilan hubungan industrial. Atas permohonan tersebut pengadilan negeri harus sudah mengeluarkan perintah pelaksanaan eksekusi selambat-lambatnya 30 hari setelah permohonan fiat eksekusi didaftarkan di pengadilan negeri setempat. Apabila ada pihak yang merasa dirugikan oleh putusan arbitrase, satu-satunya yang dapat dilakukan adalah mengajukan permohonan pembatalan putusan arbitrase ke Mahkamah Agung melalui upaya hukum peninjauan kembali. Upaya tersebut harus sudah diajukan selambat-lambatnya 30 hari terhitung sejak dikeluarkannya putusan arbitrase menurut Pasal 52 Undang-Undang Nomor 2 Tahun 2004. Adapun alasan pengajuan perjanjian kembali adalah apabila putusan diduga mengandung unsurunsur sebagai berikut: Pertama, Surat atau dokumen yang diajukan dalam pemeriksaan, setelah putusan dijatuhkan, diakui atau dinyatakan palsu; Kedua, Setelah putusan diambil, ditemukan dokumen yang bersifat menentukan, yang disembunyikan oleh pihak lawan; Ketiga, Keputusan diambil dari tipu muslihat yang dilakukan oleh salah satu pihak dalam pemeriksaan perselisihan; Keempat, Putusan melampaui kekuasaan arbiter hubungan industrial; Kelima, Putusan bertentangan dengan peraturan perundang-undangan.

Dalam jangka waktu 30 hari setelah pengajuan permohonan pembatalan, mahkamah agung harus mengeluarkan putusan. Putusan yang dikeluarkan bisa menerima permohonan pembatalan dan bisa juga menolak. Apabila diterima, maka putusan arbitrase sebelumnya akan dibatalkan dengan menyebut akibat hukum dari pembatalan. 


\section{KEUNGGULAN ARBITRASE HUBUNGAN INDUSTRIAL}

Penyelesaian sengketa melalui arbitrase dinilai menguntungkan karena beberapa alasan sebagai berikut: Pertama, Kecepatan dalam Proses. Arbitrase hubungan industrial diminati oleh para pihak yang berselisih terutama pihak pengusaha karena proses penyelesaian perselisihannya harus selesai dalam waktu 30 hari kerja. Pasal 40 ayat 1 Undang-Undang Nomor 2 Tahun 2004 menyebutkan bahwa arbiter wajib menylesaikan perselisihan hubungan industrial dalam waktu selambat-lambatnya 30 hari kerja sejak penan-datanganan surat perjanjian. Kedua, Sifat konfidensialitas. Pemeriksaan perselisihan hubungan industrial oleh majelis arbitrase selalu dilakukan dalam persidangan tertutup dalam arti tidak terbuka untuk umum. Pemeriksaan secara tertutup tersebut dapat disimpangi kecuali para pihak yang berselisih menghendaki lain. Putusan kecuali para pihak yang berselisih menghendaki lain. Putusan yang dijatuhkan dalam sidang tertutup tersebut hampir tidak pernah dipublikasikan. Dengan demikian, penyelesaian melalui arbitrase diharapkan dapat menjaga kerahasiaan para pihak yang bersengketa; Ketiga, Pemeliharaan Hubungan yang Baik. Penyelesaian sengketa melalui arbitrase hubungan industrial dapat menjaga suatu hubungan baik antara para pihak yang berselisih, sebab dalam penyelkesaian menggunakan arbitrase dilakukan secara dialogis dengan atau tanpa melibatkan pihak ketiga yang netral dan putusan hakikatnya merupakan kesepakatan para pihak. Sifat penyelesaian sengketa yang ada, win-win solution, bahwa setiap pihak tidak dirugikan dan masing-masing pihak mendapatkan keuntungan yang sembarang; Keempat, Hemat Waktu Dan Biaya; Penyelesaian melalui arbitrase hubungan industrial dinilai dapat menghemat waktu dan biaya, hal ini sejalan dengan asas dalam penyelesaian sengketa melalui arbitrase yang cepat, sederhana, dan biaya murah. Kelima, Putusan Nonyudisial; Maksudnya bahwa putusan yang dihasilkan tidak oleh lembaga hakim, tetapi lebih pada hasil kesepakatan para pihak yang bersengketa sendiri dengan atau tanpa bantuan pihak ketiga yang netral. Karena merupakan kesepakatan maka, hasil penyelesaian hakikatnya merupakan perjanjian merupakan perjanjian yang mengikat, seperti Undang-Undang, dan wajib dilaksanakan dengan itikad baik.

\section{KELEMAHAN ARBITRASE HUBUNGAN INDUSTRIAL}

Beberapa faktor yang merupakan kelemahan arbitrase adalah sebagai berikut: Pertama, Hanya untuk Para Pihak Bonafide. Arbitrase hubungan industrial terkesan hanya bermanfaat untuk para pihak atau pengusaha yang bona fide (bonafide) atau jujur dan dapat dipercaya. Para pihak yang bonafide adalah mereka yang memiliki kredibilitas dan integritas, artinya patuh terhadap kesepakatan. Kedua, Ketergantungan Mutlak Pada Arbiter Hubungan Industrial. Putusan arbitrase selalu tergantung pada kemampuan teknis arbiter untuk memberikan putusan yang tepat dan sesuai dengan rasa keadilan para pihak. Meskipun arbiter memiliki keahlian teknis yang tinggi, bukanlah hal yang mudah bagi majelis arbitrase untuk memuaskan dan memenuhi kehendak para pihak yang bersengketa. Pihak yang kalah akan mengatakan bahwa putusan arbitrase tidak adil, demikian pula sebaliknya. Ketergantungan secara mutlak terhadap para arbiter dapat merupakan suatu kelemahan karena substansi perkara dalam arbitrase tidak dapat diuji kembali (melalui proses banding). Ketiga, Tidak Ada Preseden Putusan Terdahulu Putusan arbitrase dan seluruh pertimbangan di dalamnya bersifat rahasia dan tidak dipublikasikan. Akibatnya, putusan tersebut bersifat mandiri dan terpisah dengan yang lainnya, sehingga tidak ada legal precedence atau keterikatan terhadap putusan-putusan arbitrase sebelumnya. Artinya, putusan-putusan arbitrase atas suatu sengketa terbuang tanpa manfaat, meskipun di dalamnya mengandung argumentasi-argumentasi berbobot dari para arbiter terkenal di bidangnya.

\section{PENUTUP}

Undang-Undang Nomor 2 Tahun 2004 tentang penyelesaian perselisihan hubungan industrial mengatur secara khusus mengenai penyelesaian perselisihan hubungan industrial melalui, sesuai dengan asas hukum lex specialis derogad lex generali. Arbitrase hubungan industrial dapat menyelesaikan perselisihan kepentingan dan perselisihan antar serikat pekerja/serikat buruh dalam satu perusahaan. Penyelesaian melalui arbitrase harus melalui kesepakatan tertulis dari para pihak yang berselisih untuk menyerahkan penyelesaian perselisihan kepada arbiter yang putusannya mengikat para pihak dan bersifat final. 


\section{DAFTAR PUSTAKA}

Abdussalam, 2009, Hukum Ketenagakerjaan, Jakarta: Restu Agung.

Asikin, Zaenal, dkk., 2008, Dasar-Dasar Hukum Perburuhan, Jakarta: Raja Grafindo Persada.

Asyhadie, Zaeni, 2008, Hukum Kerj, Jakarta: Rajawali Pers.

Dono, Agus, Arbitrase sebagai Salah Satu Alternatif Penyelesaian Sengketa di Luar Pengadilan. Panduan Kuliah. Surabaya: Fakultas Hukum Universitas Wijaya Kusuma.

Harahap, Yahya, 2006, Arbitrase, Edisi Kedua. Jakarta: Sinar Grafika.

Husni, Lalu, 2007, Penyelesaian Perselisihan Hubungan Industrial Melalui Pengadilan \& di Luar Pengadilan, Jakarta: Rajawali Pers.

H.P. Pangabean, 2007, Penyelesaian Perselisihan Hubungan Industrial, Jakarta: Jala Permata.

Johan Nasution, Bahder, 2004, Hukum Ketenagakerjaan Kebebasan Berserikat bagi Pekerja. Bandung: Mandar Maju.
Moch. Salam, Faisal, 2009, Penyelesaian Perselisihan Hubungan Industrial di Indonesia, Bandung: Mandar Maju.

Sutedi, Adrian, 2009, Hukum Perburuhan, Jakarta: Sinar Grafika.

Umam, Khotibul, 2010, Penyelesaian Sengketa di Luar Pengadilan. Yogyakarta: Pustaka Yustisia.

Undang-Undang Nomor 13 Tahun 2003 tentang Ketenagakerjaan

Undang-Undang Nomor 30 Tahun 1999 tentang Arbitrase dan Alternatif Penyelesaian Sengketa.

Undang-Undang Nomor 2 Tahun 2004 tentang Penyelesaian Perselisihan Hubungan Industrial.

Peraturan Menteri Tenaga Kerja dan Transmigrasi Republik Indonesia Nomor PER.02/Men/2005 tentang Tata Cara Pendaftaran, Pengujian, Pemberian, dan Pencabutan Sanksi bagi Arbiter Hubungan Industrial.

Budiono, 2005, Kamus Lengkap Bahasa Indonesia. Surabaya: Karya Agung.

Kamus Hukum, Bandung: Citra Umbara. 